surpassed. His realization of the essential unity of the antibody reactions helped to bring order into a confused field. His papers, like those of his great predecessors, are classical in quality, commendable to students.

His second great contribution to medical science wes the quality and nature of his teaching. Forty years ago, he was a very great teacher, who insisted on the interdependence of all branches of pathology and medicine. He made his students eager to know more and more about more and more. Pathology he regarded as one great subject, of which bacteriology, immunology, virology, hæmatology and morbid anatomy were all interdependent parts, and liable to suffer from individual elevation to specialist rank. He taught pathology as the true basis of all meaicine and as especially valuable for the insight it gave into normal function. $\mathrm{He}$ was, thirty and forty years ago, a brilliant lecturer; but his greatest effect was obtained when demonstrating in the laboratory.

His creation of the Part II and Part I Pathology Triposes in Cambridge has benefited many generations of Cambridge medical graduates, and, through them, the whole of medicine.

As a principal leader in the Cambridge Medical School, as Master of Trinity Hall and, during the two difficult and anxious years which preceded the Second World War, as vice-chancellor, Dean's energies were necessarily devoted chiefly to administration. Outside Cambridge, he had many activities; at various times, and for many years at a time, he was chairman of the council of the Imperial Cancer Research Fund, secretary of the Pathological Society of Great Britain and Ireland, a member of the Royal Commission on the University of Durham. $\mathrm{He}$ served on the General Medical Council as representative of the University of Manchester during 1919-22, and of the University of Cambridge during 1942-57.

He received several honorary degrees-LL.D. of the Universities of Aberdeen and Western Reserve, honorary D.Sc. of the University of Liverpool. He was a Corresponding Fellow of the New York Acedemy of Medicine.

Dean was no dilletante, but he was well informed on a very wide range of subjects. To accompany him on a wine-buying expedition for the College; or to handle and appreciate some of the silver he had collected; or to inspect his seedling viruses in Trinity Hall ; or to climb mountains with him, or swim with him, or to follow the boats in Mrys or Lent races, or sit with him on boards and committees, or hear him quote Horace with a conscientiously archaic pronunciation, or just to drop in for a chat with him-these were all memorable experiences, and for the memory of them one is grateful. But one is chiefly grateful for the example of staunch, objective honesty of outlook on everything that came within his ken, and for the irrepressible bumour of his commentary on it. An anonymous contributor to The Lancet has said "I owe it to him that I have had such an interesting life". Many others would acknowledge the same debt.

In 1908 he married Irene Wilson, who died in 1959, after being his close partner and perfect counterpart throughout a long joint career. Mrs. Dean shared the affection and regard in which he was held by many hundreds of younger people whom they helped, encouraged, guided and entertained.

E. T. C. SPooner

\author{
Prof. Jerome T. Syverton
}

Jerome T. Syverton, whose death occurred on January 28, began an outstanding, active career in microbiology as an instructor in bacteriology at the University of North Dakota in 1928. Born in Courtenay, North Dakota, in 1907, he entered the University of North Dakota in 1923, obtaining the A.B. degree in 1927 and the B.S. degree in 1928. He graduated from Harvard University School of Medicine in 1931, and after an internship and assistant residency in medicine at Duke University Hospital in 1931-32, he became an assistant in pathology and bacteriology at the Rockefeller Institute for Medical Research, New York. There he obtained basic knowledge in virology under the guidance of Dr. P. K. Olitsky, and in 1932 became a member of the faculty of the University of Rochester School of Medicine and Dentistry.

Except for a sabbatical leave in 1942 at Vanderbilt University School of Medicine as visiting associate professor of pathology and bacteriology, Syverton's fundamental and pioneering work involving, for example, tumour viruses and multiple viral infections of single animal cells, as well as the development of his outstanding skill as a teacher and student adviser, was done during 1934-47 while in the Department of Bacteriology at the University of Rochester. For his outstanding research in virology, he received the Lilly Award in Bacteriology and Immunology in 1938. During 1944 46 he was on active duty in the United States Navy as a visiting investigator at the Rockefeller Institute, and member of Naval Medical Research Unit 2 in the Pacific Theatre. In 1947 he became professor and head of the Department of Microbiology at Louisiana State University School of Medicine, and since 1948 had been professor and head of the Department of Bacteriology at the University of Minnesota.

During his academic career Syverton's enthusiastic and vigorous approach to professional life, with simultaneous devotion to his family and friends, set an extraordinary example for students and associates. His graduate and postdoctoral students during twelve years at the University of Minnesota alone numbered more than 65 . His productivity as an investigator was remarkable, and during 1957-58 he was recipient of the Commonwealth Fund Award for Creative Work. Eighty-seven articles describing his own work and 119 in conjunction with his students and associates were published between 1933 and 1960 . His stature in science and academic medicine was evidenced by his membership of many scientific advisory committees, and his enthusiastic support of science at an international and national level was widely recognized and appreciated. The world's scientific community has lost a creative and productive investigator, the educational community an enthusiastic teacher, the community of his colleagues and associates a true friend, and his family an affectionate and lovable father.

WIILIAM F. Scherer

\section{Prof. B. Davison}

PHysicists and mathematicians connected with the British and Canadian atomic energy projects have learned with regret of the sudden death of Boris Davison on January 24, while still a very productive mathematical physicist engaged on problems of neutron transport. 